\author{
IFAS Extension
}

\title{
Become Captain of Your Financial Ship, Unit 1: Charting the Course ${ }^{1}$
}

Josephine Turner ${ }^{2}$

This is Unit 1 in a 6-part series on improving personal financial management. Other publications in the series include:

Become Captain of Your Financial Ship: A Curriculum in Financial Management

Become Captain of Your Financial Ship, Unit 2: Trimming the Sails

Become Captain of Your Financial Ship, Unit 3: Standing Watch

Become Captain of Your Financial Ship, Unit 4: Stay the Course

Become Captain of Your Financial Ship: Evaluation Survey

Each unit includes PowerPoint handouts, class work, take-home assignments, and other resources.

Additional materials are available on the EDIS website (http://edis.ifas.ufl.edu) and/or other websites as identified.

\section{Unit 1: Charting the Course}

This document is only available as a PDF. Click here to access the PDF.

1. This document is FCS7221, one of a series of the Department of Family, Youth and Community Sciences, Florida Cooperative Extension Service, Institute of Food and Agricultural Sciences, University of Florida, Gainesville FL 32611. First published May 2006. First EDIS publication January 2007. Visit the EDIS website at http://edis.ifas.ufl.edu.

2. Josephine Turner, PhD, CFP, Professor, Family and Consumer Economics, Department of Family, Youth and Community Sciences, Cooperative Extension Service, IFAS, University of Florida, Gainesville, 32611.

The Institute of Food and Agricultural Sciences (IFAS) is an Equal Opportunity Institution authorized to provide research, educational information and other services only to individuals and institutions that function with non-discrimination with respect to race, creed, color, religion, age, disability, sex, sexual orientation, marital status, national origin, political opinions or affiliations. U.S. Department of Agriculture, Cooperative Extension Service, University of Florida, IFAS, Florida A. \& M. University Cooperative Extension Program, and Boards of County Commissioners Cooperating. Larry

Arrington, Dean 